\title{
Physicians' Perceptions and Expectations of Pharmacists' Professional Duties in Government Hospitals in Kuwait
}

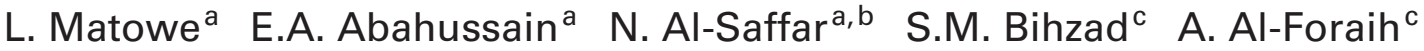 \\ A.A. Al-Kandery ${ }^{\mathrm{d}}$ \\ ${ }^{a}$ Department of Pharmacy Practice, Faculty of Pharmacy, Kuwait University, ${ }^{b}$ Pharmaceutical Services \\ Administration, Ministry of Health, ${ }^{\mathrm{c}}$ Mubarak Al-Kabeer Hospital, ${ }^{\mathrm{d}}$ Adan Hospital, Ministry of Health, Kuwait
}

\section{Key Words}

Physician-pharmacist relationships · Physicians' expectations of pharmacists - Clinical pharmacy services in Kuwait

\begin{abstract}
Objective: The objectives of this study were to evaluate the perceptions, expectations and experience of physicians with hospital-based pharmacists in Kuwait. Materials and Methods: A piloted self-administered questionnaire was hand delivered to 200 physicians practicing in four government hospitals in Kuwait. Main sections of the questionnaire comprised a series of statements pertaining to physicians' perceptions, expectations and experiences with pharmacists. Results: One hundred and twenty $(60 \%)$ questionnaires were returned. At least $57 \%$ of physicians in Kuwait appear comfortable with pharmacists carrying out patient-directed roles. In addition, they appeared to have high expectations of pharmacists, with $79 \%$ of them regarding pharmacists as knowledgeable drug therapy experts. Less than $60 \%$ considered pharmacists as applying their drug knowledge in practice and only $29 \%$ agreed that pharmacists routinely counselled their patients. There was no correlation between physician variables such as number of years since graduation
\end{abstract}

\section{KARGER \\ Fax +4161306 1234 E-Mail karger@karger.ch} www.karger.com
(C) 2006 S. Karger AG, Basel

$1011-7571 / 06 / 0153-0185 \$ 23.50 / 0$

Accessible online at: www.karger.com/mpp from medical school, age, area of practice and their perceptions of pharmacists. Conclusion: Physicians in Kuwait appear comfortable with pharmacists providing a broad range of services but appear somewhat less comfortable with pharmacists' provision of direct patient care. Physicians considered pharmacists knowledgeable drug therapy experts, but regarded them as not routinely providing a broad range of higher-level pharmacy services.

Copyright (C) 2006 S. Karger AG, Basel

\section{Introduction}

Physician-pharmacist relationships have been described in a number of studies [1-7] depicting as being complex [6, 7]. Historically, physicians diagnosed and prescribed medications while pharmacists compounded and dispensed them. In the USA and most developed countries the role of pharmacists has changed to one that plays a direct role in patient care [8,9]. However in $\mathrm{Ku}-$ wait, the old model still serves as the basis of what physicians and a large segment of the general population perceive of pharmacists.

Increased interaction between physicians and pharmacists in the developed world has produced drug therapy that is safer, more effective, and less costly $[10,11]$. In 
addition, there is increasing evidence that clinical pharmacy services play a pivotal role in the appropriate usage of medications [12-14]. Given that direct patient care, which involves interaction with, and observation of the patient, is still exclusively in the hands of physicians in Kuwait, pharmacists' input in managing drug therapy ultimately depends on physicians' willingness to accept this role. It is therefore important, that physicians understand and appreciate how pharmacists can contribute directly to the overall provision of patient care.

In a number of studies, physicians were reported to be receptive to several clinical services provided by pharmacists if these services were provided in a consultative or supportive role [15-18]. Physicians' acceptance of pharmacists' services also depends on the value physicians attached to the service and the physicians' perception of the pharmacist's competence $[19,20]$.

Prior to this study, the authors perceived physicians in Kuwait as having little awareness and receptivity to pharmacists' involvement in direct patient care. This perception emanated from the fact that pharmacists in $\mathrm{Ku}$ wait had limited expertise, training and exposure to clinical pharmacy. Clinical pharmacy is the provision of pharmaceutical services that involves interaction with, and observation of the patient [21]. In addition, the professional duties of pharmacists in the Kuwait health care system are not comprehensively covered by legislation. Hence the purpose of this study was to assess the perceptions, expectations and current experience of Kuwait physicians with hospital pharmacists' responsibilities and capabilities.

\section{Subjects and Methods}

\section{Subjects}

The study was conducted from May through July 2004. The questionnaire was hand delivered by ward secretaries to a random sample of 200 physicians in two government general hospitals: Mubarak Al-Kabeer and Adan hospitals, and two specialised hospitals: Ibn Sina and Psychiatry hospitals. Eighty questionnaires were distributed to each of the general hospitals, each with a total of approximately 200 physicians, while 20 questionnaires were distributed to each of the specialised hospitals, each with an approximate number of 50 physicians. Physicians were stratified by area of practice and selected randomly from hospital lists. To limit bias, the pharmacists participating in the study did not actively participate in the distribution and collection of the questionnaires.

\section{Setting}

Kuwait is a small country in the Middle East, bordering the Arabian Gulf, between Iraq and Saudi Arabia. In 2004, Kuwait had a population of slightly over 2.25 million people. Public healthcare facilities in Kuwait are divided into general hospitals, specialized hospitals and clinics. There are six general hospitals and at least 21 specialized hospitals and centres and approximately 80 primary healthcare centres serving the Kuwait community. Over 3,500 physicians serve in these facilities giving a physician/patient ratio of 1:700, which compares well with that in most developed countries such as USA, with an equivalent ratio of 1:625 [22]. The number of pharmacists in the government sector in Kuwait is small but has been increasing over the past few years, mainly due to the establishment of a School of Pharmacy, Kuwait University, in 1996. Currently, there are limited clinical pharmacy services in Kuwait with the current duties of hospital pharmacists mainly restricted to administrative roles such as drug orders, stock control and personnel management.

\section{Design}

The questionnaire had four sections on personal information, physician's perception, expectations and experience with pharmacists. The questionnaire was adapted from one used and validated for content in California [23]. Each part included a set of statements for which respondents were asked to indicate their level of agreement.

\section{Data Analysis}

The data were computed and analysed using the Statistical Package for Social Sciences for Windows, version 12. Various frequency values and cross tabulation between different variables were calculated. The $\chi^{2}$ test was used to determine the significance of association between categorical variables.

\section{Results}

One hundred and twenty questionnaires (60\%) were returned. Details of the physicians' personal information are given in table 1 . The average age was 41 years, $79 \%$ were male. The majority of physicians (59\%) were nonKuwaitis. There were no associations between physician variables such as age, gender, nationality, year of graduation and their perception of pharmacists.

Two thirds of the physicians said they interacted with pharmacists at least once a week (table 2). The main reasons for the interaction were queries on drug availability (79\%), alternatives (54\%), side effects (25\%) and drug interactions (18\%).

The comfort level of physician with pharmacists carrying out specific duties is shown in table 3 . The majority $(93 \%)$ of the physicians were comfortable with pharmacists detecting and preventing prescription errors, while $83 \%$ were comfortable with them providing patient education; $43 \%$ were uncomfortable with pharmacists suggesting use of prescription medications to patients and $42 \%$ were uncomfortable with treating minor illnesses. 
Table 1. Physicians' personal information $(\mathrm{n}=120)$

\begin{tabular}{|c|c|}
\hline Variable & n (\%) \\
\hline \multicolumn{2}{|l|}{$\mathrm{Age}^{1}$} \\
\hline$\leq 35$ years & $41(34.2)$ \\
\hline$\leq 36-46$ years & $42(35.0)$ \\
\hline$\geq 47$ years & $37(30.8)$ \\
\hline \multicolumn{2}{|l|}{ Gender } \\
\hline Male & $95(79.2)$ \\
\hline Female & $25(20.8)$ \\
\hline \multicolumn{2}{|l|}{ Nationality } \\
\hline Kuwaiti & $49(40.8)$ \\
\hline Non-Kuwaiti & $71(59.2)$ \\
\hline \multicolumn{2}{|c|}{$\begin{array}{l}\text { Country where medical qualification was } \\
\text { obtained }\end{array}$} \\
\hline USA and Europe & $20(16.7)$ \\
\hline Kuwait & $26(21.7)$ \\
\hline Egypt & $52(43.3)$ \\
\hline India and Pakistan & $17(14.2)$ \\
\hline Other & $5(4.2)$ \\
\hline \multicolumn{2}{|l|}{ Place of work } \\
\hline General hospital & $89(74.2)$ \\
\hline Specialized hospital & $31(25.8)$ \\
\hline \multicolumn{2}{|l|}{ Current position } \\
\hline Assistant registrar & $19(15.8)$ \\
\hline Registrar & $52(43.3)$ \\
\hline Senior registrar & $27(22.5)$ \\
\hline Consultant & $22(18.3)$ \\
\hline \multicolumn{2}{|l|}{ Current area of practice } \\
\hline Medicine & $34(28.3)$ \\
\hline Surgery & $32(26.7)$ \\
\hline Pediatrics & $18(15.0)$ \\
\hline Psychiatry & $18(15.0)$ \\
\hline Other & $18(15.0)$ \\
\hline
\end{tabular}

Table 2. Current physician interaction with pharmacists $(\mathrm{n}=120)$

\begin{tabular}{ll}
\hline Variable & $\mathrm{n}(\%)$ \\
\hline Frequency of interactions & \\
$\quad$ Never/rarely & $40(33.3)$ \\
Once a week & $63(52.5)$ \\
$\quad$ Once a day/more & $17(14.2)$ \\
Reasons for interactions & \\
$\quad$ Drug availability queries & $93(78.8)$ \\
Drug alternatives queries & $64(54.2)$ \\
Drug dosage queries & $36(30.5)$ \\
Side effects queries & $29(24.6)$ \\
$\quad$ Drug interactions queries & $21(17.8)$ \\
Other & $15(12.7)$ \\
\hline
\end{tabular}

Physicians' Perceptions of Hospital Pharmacists
Table 3. Level of physician comfort with pharmacists carrying out specific duties

\begin{tabular}{lll}
\hline Pharmacist's duty & $\begin{array}{l}\text { Physicians } \\
\text { comfort- } \\
\text { able, } \%\end{array}$ & $\begin{array}{l}\text { Physicians } \\
\text { uncomfort- } \\
\text { able, \% }\end{array}$ \\
\hline $\begin{array}{l}\text { Providing patient education } \\
\text { Suggesting use of non-prescription } \\
\quad \text { medications, e.g. paracetamol }\end{array}$ & 83.1 & 16.9 \\
$\begin{array}{l}\text { Suggesting use of prescription medica- } \\
\quad \text { tions to patients, e.g. antibiotics }\end{array}$ & 71.4 & 28.6 \\
$\begin{array}{l}\text { Suggesting use of prescription medica- } \\
\quad \text { tions to physicians }\end{array}$ & 74.1 & 43.1 \\
$\begin{array}{l}\text { Treating minor illnesses, e.g. headaches } \\
\text { Designing and monitoring pharmaco- }\end{array}$ & 58.3 & 41.7 \\
$\quad \begin{array}{l}\text { therapeutic regimes } \\
\text { Monitoring outcomes of pharmaco- } \\
\quad \text { therapeutic regimens }\end{array}$ & 73.1 & 26.9 \\
$\begin{array}{l}\text { Detecting and preventing prescription } \\
\text { errors }\end{array}$ & 72.0 & 28.0 \\
\hline & 92.5 & 7.5 \\
\hline
\end{tabular}

The physicians' expectations of pharmacists are listed in table 4. Eighty percent (80\%) expected pharmacists to be knowledgeable drug therapy experts and $77 \%$ to educate patients about the safe and appropriate use of medications. The physicians' current experiences with pharmacist are given in table 5 . While $75 \%$ of physicians concurred that pharmacists are a reliable source of drug information, only $29 \%$ agreed that pharmacists were routinely providing such information.

\section{Discussion}

Physicians in Kuwait appeared generally comfortable with pharmacists carrying out patient-directed roles, although, $42 \%$ were uncomfortable with pharmacists carrying out routine duties such as treating minor illnesses. In the USA, for example, such level of physician discomfiture with pharmacists carrying out patient-directed roles, reported more than a decade ago, was attributed to lack of physician exposure to pharmacists participating in these activities [19, 20, 24, 25]. Thus, there is a need for Kuwait pharmacists to work more closely with physicians, thereby providing the physician with an opportunity to observe pharmacists performing clinical responsibility leading to building the physicians' awareness and confidence in the pharmacists.

A large number of physicians appeared uncomfortable with pharmacists prescribing, even for a minor ailment. 
Table 4. Physicians' expectation of pharmacists

\begin{tabular}{|c|c|c|c|}
\hline \multirow[t]{2}{*}{ Physician expectations } & \multicolumn{3}{|c|}{$\%$ of physicians who } \\
\hline & agree & $\begin{array}{l}\text { are } \\
\text { neutral }\end{array}$ & $\begin{array}{l}\text { dis- } \\
\text { agree }\end{array}$ \\
\hline $\begin{array}{l}\text { I expect pharmacists to take personal re- } \\
\text { sponsibility for resolving any drug-related } \\
\text { problems they discover involving patients }\end{array}$ & 42.5 & 23.3 & 34.2 \\
\hline $\begin{array}{l}\text { I expect pharmacists to be knowledgeable } \\
\text { drug therapy experts }\end{array}$ & 79.8 & 16.0 & 4.2 \\
\hline $\begin{array}{l}\text { I expect pharmacists to assist me in } \\
\text { designing drug therapy treatment plans } \\
\text { for my patients }\end{array}$ & 49.2 & 24.6 & 26.3 \\
\hline $\begin{array}{l}\text { I expect pharmacists to educate my } \\
\text { patients about the safe and appropriate } \\
\text { use of their medication }\end{array}$ & 77.1 & 12.7 & 10.2 \\
\hline $\begin{array}{l}\text { I expect pharmacists to monitor my } \\
\text { patients' response to drug therapy and let } \\
\text { me know if a patient encounters any } \\
\text { drug-related problem }\end{array}$ & 36.6 & 28.3 & 35.0 \\
\hline $\begin{array}{l}\text { I expect pharmacists to know the specific } \\
\text { indication of each drug I prescribe, even } \\
\text { when drugs have more than one approved } \\
\text { or recognized indication }\end{array}$ & 70.6 & 18.5 & 10.9 \\
\hline $\begin{array}{l}\text { I expect pharmacists to be available to } \\
\text { me for consultation when I see patients } \\
\text { (e.g. during rounds) }\end{array}$ & 48.7 & 25.2 & 26.0 \\
\hline $\begin{array}{l}\text { I expect pharmacists to assist my patients } \\
\text { in selecting appropriate non-prescription } \\
\text { medications }\end{array}$ & 43.7 & 26.1 & 30.2 \\
\hline
\end{tabular}

This finding supports a number of previous studies that showed that physicians are reluctant to accept pharmacist roles which include any aspects of prescribing $[25,26]$.

Contrary to the apparent belief in Kuwait that physicians do not regard pharmacists highly and do not expect them to play a role in direct patient care, our study shows that physicians appear to have high expectations of pharmacists as knowledgeable drug therapy experts and expect them to educate patients about the safe and appropriate use of medications. However, physician experiences with pharmacists were less than optional as $60 \%$ of the physicians considered pharmacists as adequately applying their knowledge in practice. The probable explanation could include the pharmacist lack of confidence in his/her self. Factors contributing to the lack of confidence include insufficiency in pharmacist's clinical training and
Table 5. Physicians' experience with pharmacists

\begin{tabular}{|c|c|}
\hline \multirow[t]{2}{*}{ Physician experiences } & $\%$ of physicians who \\
\hline & $\begin{array}{l}\text { are } \\
\text { neutral }\end{array}$ \\
\hline
\end{tabular}

In my experience, pharmacists are a $\begin{array}{lll}74.6 & 16.1 & 9.3\end{array}$ reliable source of general drug information (e.g., specific facts about drugs which can be found in standard references)

In my experience, pharmacists are $\begin{array}{lll}56.8 & 23.7 & 19.5\end{array}$ reliable source of clinical drug information (e.g., information regarding the clinical use of drugs in specific situations)

\begin{tabular}{lllll}
\hline $\begin{array}{l}\text { Pharmacists routinely counsel my patients } \\
\text { regarding the safe and appropriate use of } \\
\text { their medications }\end{array}$ & 29.3 & 32.8 & 37.9 \\
\hline $\begin{array}{l}\text { Pharmacists routinely inform me if they } \\
\text { discover clinical problems with my } \\
\text { prescriptions }\end{array}$ & 57.8 & 14.7 & 27.6 \\
\hline $\begin{array}{l}\text { Pharmacists routinely inform me about } \\
\text { more cost-effective alternatives to the }\end{array}$ & 37.1 & 25.0 & 37.9 \\
\begin{tabular}{l} 
drugs I prescribe \\
\hline
\end{tabular} & & & \\
\hline
\end{tabular}

$\begin{array}{llll}\text { Pharmacists frequently ask me to clarify } & 40.9 & 24.3 & 34.8\end{array}$
for them the drug therapy objectives I have in mind for my patients

Pharmacists frequently let me know that $33.9 \quad 24.6 \quad 41.5$ my patients have experienced some problem with their medication

In my experience, pharmacists appear $29.7 \quad 26.3 \quad 44.1$ willing to take personal responsibility for resolving any drug-related problems they discover

the fact that most of the pharmacists at the time of the survey were foreigners, or foreign trained, with minimal exposure to the Kuwait healthcare system. With the establishment of the Faculty of Pharmacy at Kuwait University, it is expected that the student pharmacist training will include direct patient care during clinical rotations with physicians.

The main limitation of this study was sampling from only four government hospitals, which did not include private sector physicians. 


\section{Conclusion}

Physicians in Kuwait appeared comfortable with pharmacists providing a broad range of services, including direct patient care. Physicians considered pharmacists to be knowledgeable about drug therapy, but regarded them as not routinely providing quality range of clinically focused pharmacy services.

\section{Acknowledgements}

We would like to thank Dr. Ahmad Al Duaij, Director of Pharmaceutical Services, Kuwait Ministry of Health, for facilitating this project. We would also like to thank pharmacists Momtaz Shaikh and Ammar Al-Abbad for helping with the design aspects of the project.

\section{References}

1 Morley A, Jepson MH, Edwards C, Stillman P: What do doctors think of pharmacists treating minor ailments? Pharm J 1983;231:387-388.

-2 Grussing PG, Goff DA, Kraus DM, Mueller CE: Development and validation of an instrument to measure physicians' attitudes toward the clinical pharmacist's role. Drug Intell Clin Pharm 1984;18:635-640.

3 Griffin JF: More physician-pharmacist cooperation needed. N Engl J Med 1986;56:115118.

-4 Nesbit F, Chaplain DC, Edwards JA Jr, Fleming GR, Harker MN, Work DR, Neelon FA: Counselling of patients by pharmacists. Blessing or curse? NC Med J 1995;56:115-118.

-5 Bradshaw SJ, Doucette WR: Community pharmacists as patient advocates: physician attitudes. J Am Pharm Assoc 1998;38:598_ 602.

-6 Ranelli PL, June Biss J: Physicians' perceptions of communication with and responsibilities of pharmacists. Am Pharm Assoc 2000;40: 625-630.

7 Cowen DL: Changing relationship between pharmacists and physicians. Am J Hosp Pharm 1992;49:2715-2721.

-8 Jones EJ, Mackinnon NJ, Tsuyuki RT: Pharmaceutical care in community pharmacies: practice and research in Canada. Ann Pharmacother 2005;39:1527-1533.

-9 Volume CI, Farris KB, Kassam R, Cox CE, Cave A: Pharmaceutical care research and education project: patient outcomes. J Am Pharm Assoc 2001;41:411-420.
10 Martin S: In the physician's office: an interview with W. Ray Burns. Am Pharm 1989;NS29: 17-19.

11 Mitchell JL: Building cooperation with physicians: an interview with Charles Fortner. Am Pharm 1990;NS30:24-26.

12 Bond CA, Raehl CL, Pitterle ME, Franke T: Health care professional staffing, hospital characteristics, and hospital mortality rates. Pharmacotherapy 1999;19:130-138.

13 Leape LL, Cullen DJ, Clapp MD, Burdick E, Demonaco HJ, Erickson JI, Bates DW: Pharmacist participation on physician rounds and adverse drug events in the intensive care unit. JAMA 1999;282:267-270

14 Bero LA, Mays NB, Barjesteh K, Bond C: Expanding the roles of outpatient pharmacists: effects on health services utilisation, costs, and patient outcomes. Cochrane Database Syst Rev 2000;2:CD000336.

15 Maxby DG, Weart CW, Goodman BW Jr: Family practice physicians' perceptions of the usefulness of drug therapy recommendations from clinical pharmacists. Am J Hosp Pharm 1988:45:824-827.

$\checkmark 16$ Kirking DM, Bickley SK, Wasserman ML: Physician opinion of pharmacist initiated change from injectable to oral administration of histamine $\mathrm{H} 2$ receptor antagonists. Am J Hosp Pharm 1991;48:1722-1727.

17 Sulick JA, Pathak DS: The perceived influence of clinical pharmacy services of physician prescribing behaviour; a matched pair comparison of pharmacists and physicians. Pharmacotherapy 1996;16:1133-1141.
18 Ables AZ, Baughman OL: The clinical pharmacist as a preceptor in a family practice residency training program. Fam Med 2002;34 658-662.

19 Thomas P: Professional relationships between general practitioners and pharmacists in health centers. Br J Gen Pract 1991;41:84-85.

20 Lobas NH, Lepinski PW, Woller TW: Satisfaction of physicians and nurses with clinical pharmacy services. Am J Hosp Pharm 1991; 48:1189-1190

21 The ACCP report: ACCP defines clinical pharmacy. American College of Clinical Pharmacy 2005:24. Available at: http://www.accp.com/ report/rpt0805/art01.php.

22 Weiner JP: Prepaid Group Practice Staffing and U.S. Physician Supply: Lessons for Workforce Policy. Health Affairs. 4 February 2004. Available at: http://content.healthaffairs.org/ cgi/content/full/hlthaff.w4.43v1/DC1.

23 Smith WE, Ray MD, Shannon DM: Physicians' expectations of pharmacists. Am J Health Syst Pharm 2002;59:50-57.

-24 Bailie GR, Romeo B: New York State primary care physicians' attitudes to community pharmacists' clinical services. Arch Intern Med 1996;156:1437-1441.

25 Spencer JA, Edwards C: Pharmacy beyond the dispensary: general practitioners' views. BMJ 1992;304:1670-1672.

26 Ritchey FJ, Raney MR: Effect of exposure on physicians' attitudes toward clinical pharmacists. Am J Hosp Pharm 1981;38:1459-1463. 